\title{
MITOS DOS ÍNDIOS KAYAPÓ
}

\section{Horace Banner}

1. Os Homens do Céu

2. Como nasceu a noite

3. A origem da lavoura

4. Os peixes e outros animais

5. O fogo da onça

6. O sapo e a onça

7. As pernas do tamanduá

8. A primeira jabota

9. O jaboti e a onça

10. O homem da chuva

11. Mitos do Sol e da Lua

12. A abóbada celeste

13. Como veio a morte a ser perpétua

14. O incêndio universal

15. O dilúvio

16. O subterrâneo
17. O Pai dos Pássaros

18. Os antropófagos e o chôro

19. Contos da cozinha

20. A descoberta do milho

21. A Mãe das Cobras

22. O primeiro cantor

23. Um mito do bacurau

24. A primeira risada

25. A origem da doença

26. Perna ponteaguda

27. O mito do castanheiro

28. O primeiro machado de ferro

29. O Lago dos Cães

30. Relativo aos piolhos

31. A origem dos índios Jurúna

32. A vinda dos brancos

\section{Os Homens do Céu}

Certo dia, duas índias se detiveram para olhar como eu escrevia à máquina. Uma delas, recém-chegada ao pôsto missionário que abríramos entre os Kayapó, perguntou à outra, que já nos conhecia: "Onde estão as mulheres dêsses homens?" $\mathrm{E}$ a resposta não se fêz esperar: "Deixaram-nas no Céu quando desceram".

Apesar de não sermos mestres da língua, não havia possibilidade de nos têrmos enganado na interpretação da frase, composta que era de palavras simples. Ademais, estávamos acostumados a ouvir os índios nos chamarem de "Os Homens do Céu" (Kòikuá kam kubẽ) e isto desde o nosso primeiro encontro com êles. De início tivemos a impressão de que isto advinha do nosso hábito de cantar e orar a Deus, tentando nos fazer entender por meio de gestos.

Nessa qualidade, recebemos uma veneração inesperada. Atribuíamnos poderes sobrenaturais de tudo saber, tudo poder, tudo possuir. Julgavam-nos invulneráveis à doença e acreditavam que, por meio de nossos "frutos" (pidjô), podíamos fazer desaparecer tôdas as moléstias que os afligiam. Era patética a fé que tinham em nossas humildes pessoas.

Não se cansavam de nos perguntar como e por onde tínhamos feito nossa descida das alturas e como se podia viver num lugar em que não existe terra firme (pùká kìt) Quiseram saber se os terçados Collins e 
os espelhos, artigos cuja fabricação não podiam sequer imaginar ,também tinham vindo do Céu. $\mathrm{E}$ em várias ocasiões os tuchauas nos falaram em tom baixo e confidencial, pedindo que nunca usássemos contra êles "aquilo com que se queima a terra" (pùká madjóro-djó), que acreditavam existir dentro de nossa casa. Mostravam-nos vestígios de pele de cobra, pele velha largada no processo de criar nova por cobras e aranhas, alegando que nós também possuíamos o segredo da renovação.

Essa desmerecida estima serviu-nos de extraordinária proteção nos primeiros meses do contacto, que bem poderiam ter sido perigosos. Aos poucos, porém, havia de vir a desilusão. Os índios nos viram doentes, cansados e zangados. A maravilhosa vitrola deixou de funcionar quando a corda se quebrou. Mostrámo-nos incapazes de extrair dos ares música e mensagens quando se gastaram as pilhas de nosso pequeno rádio. Um prego no motor de pôpa reduziu a "canoa-trovão" (kó-krikritira) a um simples ubá, movido a remos e varas. E a decepção final veio no dia em que, indo nos banhar com os índios, êles viram nossos umbigos, prova irrefutável de nossa origem terrestre.

Deixaram, assim, de usar a expressão "Homens do Céu" para nos designar. E, quando a língua indígena deixou de ser para nós um quebra-cabeça, ouvimos a história que dera origem à estranha reverência que nos tinham prestado. Contaram-nos, então, que, no princípio, seus antepassados tinham descido do Céu.

O universo dos Kayapó consiste em três andares: Céu, Terra e Subterrâneo. Êles, e quase tudo o que de bom existe na Terra, se originaram no Céu.

A terra foi descoberta por um caçador celeste. Cavava êle para desentocar um tatu, o mais antigo dos animais, quando, de repente, o solo se the abriu aos pés o tatu desapareceu no espaço aberto. O caçador conseguiu salvar-se agarrando-se a uma raiz. Olhando para baixo, ficou tonto ante a visão do abismo, mas divisou um novo mundo, com florestas, campos e vastos buritizais.

Voltando à aldeia, contou o que havia acontecido e os tuchauas resolveram mudar-se do Céu para a Terra. Naquele ano, plantaram muito algodão. Do algodão, as mulheres fizeram fio. Do fio, os homens fizeram uma corda grossa. Quando esta tocou a Terra, começou a descida geral.

Metade do povo desceu sem novidade, mas a outra metade, atacada de "nó kará", hesitava. Foi quando um certo Kubê-Kra (Filho do Homem) cortou a corda e fêz a divisão entre os índios do Céu e os da Terra.

\section{Como nasceu a noite}

Tendo feito uma tradução do primeiro capítulo da Gênese, chamei os índios para ouvi-1a, esperando, além de interessá-los, ter oportunidade de corrigir os eventuais erros. 
Ouviram-me com a maior atenção, admirados de que no livro houvesse palavras que compreendiam tão bem.

"E a terra era sem forma e vazia, e havia trevas sôbre a face do abismo, e o Espírito de Deus se movia sôbre a face das águas. E disse Deus: Faça-se a luz. E a luz foi feita".

"Não pode ser!" interrompeu um dos meus ouvintes mais atentos. "O livro está dizendo que veio a noite primeiro e que depois veio o dia? Não pode ser. A noite veio agora. E' a luz que é velha".

Retruquei imediatamente que Deus é Luz e que com Êle não há trevas. Que as trevas reinavam somente na Terra.

$\mathrm{E}$ foi assim que ouvi, pela primeira vez, como nasceu a noite.

No princípio, não havia noite. Os índios viviam num Dia eterno, a Fonte de Luz ( $A$-ú-krô), sob o qual comiam, dançavam e cantavam numa alegria sem fim.

$\mathrm{Na}$ aldeia vivia um pajé (ôaiangá) que tinha entre os seus objetos um pequeno pacote embrulhado com fôlhas e amarrado com embiras.

"Que é que tem no pacote, meu tio?" perguntou um curumi.

"Nada para menino saber", foi a resposta.

Então o menino resolveu aguardar uma ocasião oportuna para resolver o mistério do embrulho.

Certo dia, o tio saiu de casa, deixando o embrulho na canastra. Era a oportunidade que o sobrinho esperava. Tomando o pacote proibido, começou a desembrulhá-lo, fôlha por fôlha, sem nada encontrar de extraordinário. Mas quando abriu a última fôlha, saiu uma pequena fumaça, escura, mas sem cheiro nem calor.

A fumaça não demorou a crescer, tornando-se densa. O curumi, sem poder recapturá-la, arrependeu-se por ter violado o segrêdo do tio. A fumaça alastrou-se por todos os lados, como uma nuvem escura. Encheu a casa, envolveu a aldeia tôda, invadiu a floresta ao redor.

Como naquele tempo não havia fogo no mundo, os índios voltaram às apalpadelas para a aldeia. Sòmente o pajé sabia o que tinha acontecido. Como castigo, o sobrinho desobediente foi transformado numa coruja e condenado a viver nas trevas que soltara na terra dos homens.

Os demais índios resolveram sair em procura da Luz perdida. Espalharam-se pelas matas. Como não podiam enxergar para achar comida, ficaram magros e doentes. Muitos morreram de fome; outros, de saudade da Luz desaparecida.

Depois de muito tempo, os sobreviventes divisaram um pequeno clarão à distância. Estavam salvos. Mas não era mais a Terra de Luzsem-fim. O Dia já estava misturado com a Noite e assim continua até hoje.

Para os índios, uma noite escura é Noite-nuvem-espêssa. (Akamot kakrãn túk). 


\section{A origem da lavoura}

No princípio a Terra não era nem boa, nem farta. Não havia peixes ou outros animais. Não se conhecia o Fogo. Não existiam frutos ou legumes. Os índios alimentavam-se de farelo de palmeira em decomposição, de largartas e orelha-de-pau.

Um dia, um jovem índio, andando pela mata, viu sentada em seu caminho uma linda moça. "Quem és tu?" perguntou êle. "De onde viestes"? "Vim do Céu" respondeu ela. "Meu pai e minha mãe ralharam comiço e vim embora, descendo com a chuva".

Visto que todos os índios tinham descido do Céu, embora por outro caminho, o rapaz não duvidou e alegrou-se, na esperança de ter uma noiva, que na aldeia êle não tinha.

A moça era acanhada e tinha receio de encontrar-se com as outras índias. Deixaram anoitecer e, sob a cortina das trevas, chegaram na casa da mãe do rapaz, onde, sem que ninguém visse, o índio acomodou a moça num enorme jamarú (cabaça), cuja bôca lacrou com cêra). A moça passava os dias escondida, esperando a noite, quando o namorado a fazia sair.

Quando, afinal, o amor clandestino foi descoberto pela mãe do rapaz e a cabaça foi aberta em plena luz de dia, a menina abaixou a cabeça e custou a levantar-se. Todos admiraram a beleza da filha do Céı e trataram de enfeitá-la como Kayapó, com a cabeça raspada no alto e o corpo pintado de urucu e jenipapo. Deram-lhe o nome de Nhokpôktí.

Nhokpôktí gostava de falar do Céu e da fartura de frutos e legumes que lá havia.

Disse ela um dia ao marido que estava enjoada de comer lagartas e pau podre e que queria voltar ao Céu para buscar algumas sementes. Explicou como êle devia fazer uma roçada, limpando a terra e preparando-a para receber as plantas trazidas do Céu.

De manhã, foram as dois ao campo onde Nhokpôktí indicou uma árvore alta e flexível. Treparam até o alto e o pêso de ambos fêz com que o tronco dobrasse até ao chão. "Solta!" mandou a índia. E o marido, obedecendo, viu a espôsa aremessar-se no espaço, entrar e desaparecer no Céu.

Fêz a roçada e, um dia, encontrou Nhokpôktí sentada no meio dela, cercada de rebentos de bananeiras e mandioca, batatas e inhames. Veio do Céu, na mesma ocasião, o primeiro beiju de mandioca, embrulhado em fôlhas de banana em forma de estrêla.

Nhokpôktí fêz uma nova viagem para mostrar aos pais o filho que the nascera aqui na Terra. Subiu por uma casa alta de cupim. Depois de criado o menino, a mãe tornou a subir, para nunca mais voltar.

Os índios continuam fazendo suas roçadas, ano após ano, cabendo às mulheres plantar a terra preparada, como boas filhas da Mãe da La- 
voura que são. $E$, quando fazem seus beijus de mandioca, ainda arranjam as fôlhas de banana em forma de estrêla, como Nhokpôktí lhes ensinou a fazer.

\section{Os peixes e outros animais}

Há uma festa entre os Kayapó que é exclusiva das mulheres. Celebrada quase todos os anos, começa com as primeiras chuvas e continua até pleno inverno. Tôdas as índias dela participam. Os homens limitamse a olhar e a arranjar jabotis em grande quantidade para o último dia da festa, o mais importante de todos.

Começa um dia, de tardezinha, quando as mulheres se reunem para pintar o corpo com tinta preta. Os desenhos são sempre uniformes e, pelo menos no princípio da festa, aplicados sem grande esmêro. Feito isto, as índias sentam-se no chão para cantar, erguendo e baixando os braços em movimento rítmico.

No dia seguinte, quando acaba a tarefa da manhã, que quase sempre leva as mulheres às roças, passam uma hora andando de duas a duas pela aldeia tôda e em tôdas as direções. Geralmente deixam de lado qualquer vestígio de roupa e usam apenas um ligeiro enfeite de fôlhas ou flores sôbre a cabeça. E assim vão, andando e cantando, os braços subindo e descendo como em súplica, os passos cadenciados, a beleza selvagem ostentando-se perante os homens que fingem uma atitude de indiferença.

Estas exibições continuam quase diàriamente por semanas inteiras, faça sol quente ou caia chuva fria. Cada dia se acrescenta novo enfeite de côr mais viva, uma pintura mais complicada, uma canção mais aperfeiçoada.

No grande dia em que termina a festa, ninguém faz outra coisa senão enfeitar complicadamente as festejantes, ou preparar infelizes jabotis para a fogueira. Quando, à tarde, as índias emergem de seu "salão de beleza", o fazem em tôda a sua glória primitiva, os crânios recémraspados, os cabelos salpicados de penugem branca, as faces com uma crosta de pó azul com látex, e, em volta da cabeça e dos ombros, lindas coroas de penas de arara. Dançam sós a noite tôda, comemorando o tempo em que as suas antepassadas remotas resolveram condenar os homens a viverem sem elas.

Conta a lenda que havia um índio de nome Birá, verdadeiro Don Juan das selvas, que exercia tal atração sôbre as mulheres, que tôdas ficavam perdidas de amor por êle. Como era de esperar-se, os maridos, ciumentos, the votavam o maior ódio. Usando de encantamentos, conseguiram que Birá se transformasse em anta, mataram-na e levaram-na para a aldeia como caça comum. Só após terem comido tôda a carne é que as mulheres foram informadas da natureza do repasto. 
Ante a verdade horripilante, as índias vomitaram não só de nojo, mas de tristeza e de raiva pela morte daquele que lhes fôra tão querido.

Mais tarde os homens foram caçar, deixando as mulheres sob a vigilância de uns velhos que passavam o tempo na casa-dos-homens, preparando armas. As mulheres resolveram fazer uma festa e para isso se pintaram cada qual a seu gôsto, umas com manchas pretas, outras com listas. Depois de pintadas, e ainda desgostosas pela morte de Birá, dirigiram-se ao rio para nunca mais voltar. Pulando na água, transformaram-se em peixes. Os velhos, que procuraram detê-las, viraram arraias e poraquês.

Ao voltarem da caçada, os homens acharam a aldeia abandonada, só restando as crianças que, chorando de fome, contaram que as mães haviam desaparecido. Indo ao rio, os índios notaram que havia peixes, criaturas que até aquêle tempo não existiam e, vendo as manchas e listas do pacu, tucunaré e outros peixes pintados, acreditaram no que as crianças haviam dito.

Cheio de saudades da mulher desaparecida, um marido desconsolado inventou a primeira linha de pescar e, por meio de uma isca de fruta silvestre (ingá), amarrada a um cipó comprido, conseguiu apanhar um peixe. Esste, arrastado à terra, tomou novamente a forma humana $\cap$ que conseguiu fazendo muitos esforços com a cabeça e a ponta do rabo. ("Veja", dizem os índios, "como até hoje os peixes fazem assim.") Quando os demais índios viram que aquele conseguira, com cipó e ingá, recuperar a mulher, tentaram fazer o mesmo, porém sem resultado. As mulheres que pescaram, zangadas ainda, pularam novamente na água para nunca mais voltar.

Tristes e inconsoláveis, achando impossível viver sem as mulheres, os maridos entraram na floresta, onde se transformaram em macacos e outros animais.

$\mathrm{E}$ até hoje, na festa chamada "Mebiôk", as índias comemoram a época dos primeiros peixes e sua independência em relação aos homens.

\section{O fogo da onça}

Certo índio, vagando pela floresta, notou que no cume de um rochedo alto e escarpado havia um casal de araras no ninho. Resolveu buscar na aldeia quem o ajudasse a tirá-los. No dia seguinte voltou com um rapazinho de nome Bctoque, que conseguiu subir por meio de uma escada por êles confeccionada.

"Não têm filhotes, cunhado! Só têm dois ovos", gritou de cima o rapaz.

"Joga-os", mandcu o outro.

Mas em vez de ovo, pegou uma pedra, e atirou-a.

"Vai outro!" gritou o rapaz. 
E o segundo ovo se transformou ttambém em pedra, como o primeiro, ferindo a mão do índio que estava em baixo; êste zangado, derrubou a escada e foi embora, não compreendendo que as araras eram encantadas ("oaianga").

Botoque passou muitos dias isolado, sem ver ninguém. Ficou magrinho e com tanta fome e sêde que comia os seus próprios excrementos. Afinal, um dia viu passar uma onça pintada, armada de arco e flechas, carregando tôda espécie de caças. Quis gritar, mas teve medo.

A onça, vendo no chão a sombra do rapazinho, quis pegá-lo, mas, não podendo, ergueu os olhos e viu, muito em cima, aquêle a quem a sombra pertencia. A onça sabia falar, e daí a pouco, o índio estava lhe contando a história.

Tendo consertado a escada, a onça mandou que êle descesse, mas quando Botoque chegou perto, vendo como a onça era grande, teve medo e subiu ncvamente. Isto fêz diversas vêzes. Quando, afinal, se achava em terra, disse-lhe a onça amiga: "Monta, vamos embora para casa, onde há muita cerne assada". O índio não sabia o que significava "assada", pois naquele tempo só se comia carne crua. Ninguém conhecia o fogo.

Quando chegaram ao covil da onça, Botoque viu um grande tronco de jatobá aceso e fumagando. Viu tambén, por tôda parte, montículos de pedras, do tamanho de côcos babaçu. Eram os primeiros fornos, protótipos do " $k i$ ", hoje usado por todo índio Kayapó. Como o menino achou boa a primeira refeição de carne moqueada!

A mulher da onça, que era uma índia, mostrou logo grande antipatia pelo recém-chegado, ao qual chamava de "me-on-kra-tum" (o filho alheio ou abandonado). Apesar dos protestos da mulher, a onça, que não tinha filho próprio, resolveu adotá-lo.

Tôdas as manhãs a onça saía para caçar, deixando o "filho" com a mulher, cuja aversão ao rapaz crescia diàriamente. Quando o menino pedia o que comer, ela só the dava carne dura e velha, ou embrulhos que pareciam beijus, mas que eram sòmente folhas. Quando êle reclamava, a madrasta the arranhava as faces e sobrancelhas, obrigando-o a fugir para a mata até que o "pai" voltasse.

A boa onça sempre repreendia a mulher, porém sem con:eguir que esta deixasse de maltratar o filho. Um dia, a onça fêz um arco novo e algumas flechas, e deu-os de presente a Botoque, ensinando-o a manejálos. Aconsethou-o também que êste atirasse na madrasta, caso esta continuasse a persegui-lo. O que de fato aconteceu, cravando-lhe uma seta no peito. Amedrontado com o que praticara, resolveu fugir, levando as armas e um pedaço de carne assada em rumo do antigo lar.

Uma escuridão total envolvia a aldeia, pois chegou de noite, e só acertou a esteira da mãe dêle às apalpadelas. A mãe, que ainda andava triste pela perda do filho, ficou muito espentada. Ajuntando-se todo 
- povo da aldeia, Botoque contou a sua história e distribuiu carne assada para todos provarem.

No dia seguinte, os índios foram buscar o fogo. Quando chegaram ao covil da onça, esta, como de costume, já havia saído para a caça. Não acharam vestígios da mulher morta, mas tôda a caça do dia anterior estava inteira e crua por não haver quem a moqueasse. Os índios ficaram maravilhados ao ver o fogo, tratando logo de assar tudo quanto havia de carne.

Eram tantos índios que conseguiram carregar o tronco todo, sem deixar uma brasa sequer naquele lar. Para a onça nada ficou. Únicamente o passaro azulão apanhou um pedacinho de brasa, graças ao qual aquenta até o dia de hoje o seu ninho.

Como se tornou alegre a aldeia desde aquela primeira noite, quando, terminado o "black-out" secular, os índios podiam dançar à luz das fogueiras, apreciar a carne moqueada e, depois, dormir tranqüilos à beira do fogo!

Quanto à onça, esta ficou triste e zangada com tudo o que lhe fizera o ingrato filho de criação, roubando-lhe tanto o fogo como o segrêdo de arco e flecha. A onça ficou apenas com o reflexo do fogo nos olhos, que brilham ainda no escuro. Caçs com os próprios dentes e come sòmente carne crua, pois jurou nunca mais comer carne assada. E até hoje odeia a tudo e a todos, especialmente aos que são do gênero humano.

\section{O sapo e a onça}

Sentado junto de um igapó, um sapo viu chegar a onça, a grande inimiga de todos desde que lhe roubaram o fogo. (Veja "O fogo da onça") . era capaz.

"Djam ga?" (és tu?) perguntou o sapo, na voz mais doce de que

"Quem é, tão pequenino, fraco e feio que está falando comigo?" perguntou a onça.

O sapo não se sentiu insultado. "Você, onça, me acha fraco e feio", prosseguiu êle, "mas vamos ver qual de nós dois é o mais valente (okrê)".

A princípio, a onça não deu importância ao desafio de rival tão insignificante, mas visto êle insistir, aceitou-o afinal.

"Ronca tu primeiro", disse o sapo. "Depois, eu coaxarei, e vamos ver quem terá mêdo".

A onça urrou com tal estertor que a própria terra tremeu e, tomados de pânico, todos os animais das florestas ao redor fugiram para longe. Sòmente o sàpo, calmo e indiferente, permaneceu imóvel.

"Coaxa tu agora, sapo", zombou a onça.

O sapo limitou-se a erguer o queixo e a soltar um coaxar baixo, em nada diferente de sua voz natural. Mas, naquele momento, todos os demais sapos que habitavam o igapó fizeram côro com êle. Sapos de 
tôda espécie, jias, rãs e cururus, sapos da lama e sapos das árvores, erguendo os queixinhos, coaxaram em uníssono.

Foi a vez de a onça correr e tão precipitada foi a fuga que um tôco lhe arrancou um ôlho!

\section{As pernas do tamanduá}

Antigamente, como todos os outros animais, o tamanduá corria regularmente bem. Naquele tempo, êle tinha as pernas compridas. No dia em que a onça perdeu a aposta com o sapo (Veja "O Sapo e a Onça"), foi o tamanduá o primeiro animal que viu a onça com um ôlho fora da órbita. Oferecendo-se para colocar-lhe o ôlho no lugar, fêz uma traição e, com as unhas compridas, arrancou o outro também.

A onça teria continuado cega até hoje, não fôsse a compaixão do inambú azulão. O azulão tinha ficado com um pouquinho do fogo da onça e por isso ofereceu-se para procurar os dois olhos perdidos e colocá-los no lugar grudando-os com resina de almôcega. Quando acabou, a onça tratou de vingar-se da traição do tamanduá.

O tamanduá correu muito, mas, não podendo com a onça e vendo-se quase perdido, escondeu-se na cova de um caititu. Mas esta era rasa demais e não deu para entrarem os pés, apesar de todos os esforços que fêz para recolhê-los. Como o tamanduá tinha muita fôrça nos braços, o inimigo não conseguiu desalojá-lo; porém, comeu-lhe os pés que ficaram de fora.

O tamanduá, coitado, escapou com vida, mas ficou até hoje com as pernas curtas.

Dizem os índios que o tamanduá fugiu da onça sòmente aquela vez. ão foge mais. Defende-se dessa sua inimiga eterna, enfrentando-a com os braços abertos.

\section{A primeira jabota}

Há um desenho empregado pelas índias na pintura do corpo, a que chamam de kapran-ôk, ou "pintura-moda-jabuti". E' um desenho usado em honra ao nascimento de sobrinho.

Conta-se que certo casal foi tirar o fruto da bacadeira, estando a mulher recém-pintada com kapran-ôk, que, naquêle tempo se conhecia por outro nome, pois ainda não existia jaboti no mundo. Vendo um cacho de fruto maduro, o homem trepou para apanhá-lo, deixando a mulher ao pé da árvore para guardar-lhe as armas.

Nisso apareceu um indivíduo procurando seduzir a mulher, que, resistindo, foi transformada em jabota, pois o agressor era feiticeiro. Ao descer com a bacaba, o marido viu as flechas e a jabota, porém sem imaginar que esta era a espôsa em forma animal. Julgando que ela tivesse voltado à aldeia, apanhou a jabota e foi-se embora. 
Os índios receberam a estranha criatura como grande novidade, achando interessante a casca laminada e o desenho tão parecido com a pintura das mulheres.

Ninguém dava notícias da mulher desaparecida.

Quando ficou só, o marido amarrou a jabota numa travessa da casa, e lá ficou ela, estincado as pernas e o pescoço em vão esfôrço para recuperar a forma humana. Não conseguindo, procurou chamar a atenção do marido roncando ba..ba..ba, que quer dizer eu..eu. .eu.. na língua kayapó. Afinal, começou a cantar e, ouvindo os cantos da maloca, o marido identificou a infeliz jabota.

Foi um feiticeiro amigo que thes restaurou o corpo de gente. Mas os jabutis ainda levam, na casca, os vestígios da sua origem humana.

Hoje, não são os homens que sobem nas bacabeiras. São as mutheres que colhem todos os frutos silvestres, enquanto os homens, armas em punho, se mantêm prontos para enfrentar e matar qualquer inimigo que apareça.

\section{O jabuti e a onça}

A onça sempre desprezou o jabuti por ser muito vagaroso e ter a voz muito fraca.

Um dia o jabuti convidou-a para uma prova de fôrça e resistência. Encontrando uma cova, o jabuti entrou e mandou fechar a entrada, dizendo à onça para voltar depois de muitos dias.

"Djam ga?" (És tu?) perguntou a onça, quando voltou.

"Ba" (Eu) disse o jabuti, sem revelar nenhuma mudança na voz.

Tempos depois a onça repetiu a pergunta e recebeu a mesma resposta. A voz continuava firme. Afinal, disse o jabuti ser a vez de a onça demonstrar a sua resistência quando estivesse, também, sem ar, sem água e sem comida.

$\mathrm{Na}$ primeira visita, a voz da onça continuava mais ou menos forte. $\mathrm{Na}$ segunda, respondeu ao jabuti em tom muito baixo. $\mathrm{Na}$ terceira, não respondeu. existir.

E um enxame de môscas sobrevoava a onça que tinha deixado de

\section{O homem da chutva}

Era um dia de setembro, um dia que amanheceu como muitíssimos outros anteriores, um dia de verão, sem nuvens no céu, nem vestígios de chuva. LIas quando o vento de meio-dia começou a soprar, vinha cálido do ocidente e não do leste como costumava. Â tarde ouviu-se uma trovoada a grande distância, mas logo a seguir apareceu uma nuvem espêssa que subia do nascente, avançando com ameaças e dizendo, numa língua que todos compreendiam, que com ela vinha o inverno. Intimidados, os passarinhos deixaram de cantar e os sapos de coaxar. Não se 
ouvia nenhum som e tudo estava imóvel. Sòmente nas casas dos índios havia agitação, preparativos febris para receber o temporal que avançava ameaçador.

$\mathrm{Na}$ penumbra daquela atmosfera eletrificada, os guerreiros sairam como quem vai expulsar um agressor. Com cabeças recém-raspadas, corpos pintados de prêto, tendo nas mãos armas de tôda espécie - rifles e espingardas, cacêtes e lanças, arcos e flechas - formavam uma frente capaz de intimidar os mais corajosos. Mas apesar de tiros e gritos, a tempestade desencadeou-se sôbre a aldeia com uma fúria tremenda, levantando nuvens de poeira, suspendendo palhas, arrancando capotes e. derribando casas inteiras. Diante disso, os índios tiveram que desistir. As mulheres se puseram a chorar e todos procuraram abrigar-se nas casas que ofereciam mais segurança.

Bekororoti estava zangado, zangado mesmo, em nada tendo diminuído o poder dos seus trovões e relâmpagos, nem o seu antigo ódio aos filhos da Terra.

Mas Bekororoti já fôra índio. Fôra casado como os demais, tinha pescado e caçado com os outros, e nada indicava que diferisse, de qualquer maneira, de seus companheiros.

Um dia, Bekororoti teve um grande desgôsto. Mataram uma anta e, apesar de ter ajudado tanto a matá-la como a esquartejá-la, Bekororoti ficou sem carne, recebendo apenas a pele, que desprezou. Não quis banhar-se e ficou sentado na casa dos homens, com o corpo manchado de sangue. No dia seguinte, não quis acompanhar os caçadores, conservando-se em casa. Ali raspou a cabeça, desde o alto até a fronte, e pintou o corpo de prêto, costumes até então desconhecidos e, armado de uma espada de pau, chamou a mulher e abandonou a aldeia.

Quando os caçadores voltaram, enquanto esperavam, sentados na casa dos homens, que as mulheres, assassem a caça, ouviram gritos vindos de um outeiro vizinho. Lá estava Bekororoti, zangado ainda, desafiando a todos para que fôssem lutar com êle. Falava com tanta insolência e teimosia que os índios não encontraram outra saída senão matá-lo.

Mas quando pegaram os arcos e flechas e procuraram fazer pontaria, ficaram paralisados por um fogo que reluzia nos olhos de Bekororoti. E, quando avançaram para ver de perto, o índio brandiu o espadão, que despediu raios e descargas e fulminou a todos. Depois disso, Bekororoti subiu ao Céu e desapareceu.

Pouco tempo depois, o mundo todo foi visitado por um temporal, vindo dos céus pela primeira vez, sendo a chuva, o trovão e o relâmpago as armas com que, até hoje, Bekororoti, o espírito do mau tempo, continua a flagelár a humanidade. 
O arco-íris não é, para o índio Kayapó, celeste, mas o "forno grande" em que a mulher de Bekororoti faz os seus bolos de mandioca.

Desde então os índios adotaram o costume de raspar a cabeça e pintar o corpo, na esperança de assimilar alguma coisa da bravura de espírito de Bekororoti. Dos nomes dados aos homens da tribo, são muitos os que começam com a sílaba $B e$ ou $B e p$, dos quais o valente deus das tempestade é considerado o padroeiro.

\section{Mitos do Sol e da Lua}

Como os peixes e animais pertenceram no início ao gênero humano, assim também o Sol e a Lua.

O Sol era um índio valente, a Luz um índio manso. Quando, depois de terem caçado juntos, a Luz reclamou que o Sol tinha ficado com a gordura tôda, o Sol zangou-se e atirou a comida quente em sua companheira, queimando-lhe a barriga. São as cicatrizes da queimadura que hoje aparecem como manchas lunares.

A Lua, desapontada e contrariada, deixou a Terra e passou para o Céu. O Sol, sempre perseguidor, foi atrás dela, porém sem nunca alcançá-la. Malogrados os seus intentos contra a Lua, o Sol começou a perseguir os filhos da Terra, especialmente os que moravam no nascente. Enviava-lhes um calor tão abrasador que seus cabelos ficaram da côr do fogo. Em represália, os índios atiraram muitas flechas ao Sol. E estas ainda são visíveis, como raios solares, ao nascer e ao pôr do sol.

\section{A abóbada celeste}

$\mathrm{Na}$ terra do nascente havia uma coluna chamada "koikuá-krait", ou Extremidade do Céu, que suportava o pêso do Céu. Naquele tempo, o Céu era paralelo à Terra.

Uma anta começou a roer a coluna, mas esta resistiu por muito tempo a todos os esforços feitos para derrubá-la, uma vez que de noite, saravam as dentadas recebidas durante o dia. O dia era tempo insuficiente para a anta completar a obra, e somente quando aprendeu a trabalhar durante a noite é que conseguiu lançar por terra a coluna. Quebrada a base que o sustentava, o Céu arreou nas extremidades, formando a Abóbada Celeste.

O caminho para o nascente é hoje intransitável, devido à mata densa, que ninguém pode penetrar.

\section{Como veio a morte a ser perpétua}

Por que não pregar a tampa do caixão fúnebre? Para que a mão cheia de terra lançada por cada um dos assistentes ao funeral? Qual o motivo de o coveiro deixar de calcar a terra com que enche a sepultura? Não são todos os civilizados que podem dar a razão dos costumes que seguem. Os Kayapó sabem explicar os ritos praticados no cemitério in- 
dígena. Se não calcam a terra que amontoam em cima da sepultura é pelo motivo exposto no mito que se segue.

Antigamente, a morte não era permanente. Os corpos passavam pouco tempo no chão antes de ressuscitarem, e os jazigos eram de formato apropriado para quem não havia de permanecer no Subterrâneo. Foi esta a origem da sepultura redonda até hoje usada pelos Kayapó.

Para fazer uma sepultura, o cavador senta-se de cócoras e, com um ferro ou pau ponteagudo, cava ao redor do seu próprio corpo, que baixa, dedo por dedo, à medida que escava. A cova pode ter de bôca apenas 60 centímetros ou duas vêzes esta largura e de um metro a um metro e meio de profundidade. Vai o morto ao seio da terra adornado de todos os símbolos da sua posição social. Dobram-se-lhes os joelhos para que fique meio sentado na esteira que forra o sepulcro. A cabeça fica erguida, apoiada na parede. Não cai sôbre êle terra alguma. Fecha-se a cova por meio de uma grade de varas grossas, que, forrada de esteiras, suporta o pêso de um monte de terra. Não se calca, absolutamente, essa terra.

Crê-se que foi a Lua uma noite que, por motivo desconhecido, deixando a órbita celeste, veio calcar a sepultura de uma criança morta, ato ímpio e arbitrário que pôs fim à esperança de ressurreição e tornou perpétua a morte.

Os Kayapó não esperam mais a ressurreição da carne. E' sòmente a alma que sai e que sobrevive. A alma de criança de peito volta de noite à procura do seio materno. E' para não incomodar as vizinhas que a mãe deixa uma cuia de leite ao lado do pequeno cadáver.

Se os mortos não ressuscitam, por que, então, deixar a terra fôfa? Por que os Kayapó não querem fazer coisa alguma que possa contrariar uma alma. Não pronunciam mais o nome que levou em vida, não fazem um gesto sequer que transforme o defunto em espírito inimigo. Até hoje, para os Kayapó, a Lua é aitchuêra (mau) enquanto o Sol é meitira (bom), e isto apesar de sua antiga fama de valentão e perseguidor da família humana.

\section{$14 O$ incêndio universal}

A preguiça certa vez roubou fogo, mas, como andasse muito devagar, as árvores se incendiaram sem que ninguém pudesse deter as labaredas. Morreram todos, salvo um pajé e sua família. O ôaiangara fêz um círculo de penas de jacamin e regou a terra de dentro da circunferência com a água de umas batatas de côr escura. O fogo não pôde passar e a famlia foi salva para tornar a povoar a Terra.

\section{O dilúvio}

Um caçador de tatu, cavando, descobriu o que julgava ser um cipó grosso. O "cipó" era a artéria da Terra e, quando cortado, jorrou 
água em tal quantidade que o mundo ficou inundado. Os animais morreram, mas os índios treparam nas árvores mais altas que não ficaram submersas. As águas demoraram muito a baixar e os sobreviventes ficaram tão magros e fracos que não puderam descer. Mas não morreram. Transformaram-se em vespões e cupins que, até hoje, fazem suas casas nos topos das árvores, revelando sua origem humana.

Do dilúvio, como do fogo universal, salvou-se apenas uma família. Uma velha fechou-se, com um casal de crianças, dentro de um pilão grande, lacrando a abertura com cêra. $\mathrm{E}$ várias sementes foram conservadas em cabacinhas amarradas ao pilão.

\section{O subterrâneo}

O universo do índio consiste de três andares, o Céu, a Terra e o Subterrâneo, como já tivemos oportunidade de dizer.

Os índios se originaram no Céu. O descobridor da Terra foi o tatu, o mais antigo de todos os animais. Quem descobriu o Subterrâneo foi o mesmo tatu que vive sempre cavando.

Conta a lenda que dois caçadores descobriram um buraco no qual se achava o tatu caiangá, ou feiticeiro. Quanto mais cavavam, mais o tatu descia, mas afinal um dos índios conseguiu agarrar-lhe 0 rabo. Como o tatu era encantado, em vez de o índio arrancá-lo, foi vencido na luta que se travou e arrastado para as profundezas da terra.

Triste e espantado, o companheiro voltou para a aldeia, onde relatou a sorte do outro. Foram todos os índios para o lugar da tragédia e ouviram, debaixo dos pés mas à grande distância, a voz do desaparecido que cantava. Dias depois, e com muito esfôrço, conseguiram chegar à grande profundidade onde êle estava, vivo e são. Porém, ninguém ousava explorar o subterrâneo recém-descoberto.

O Subterrâneo, para o índio, é a perdição final. Até hoje o índio caça tatu com muito cuidado, furando-lhe o espinhaço o mais cedo possível. Puxar pelo rabo de um tatu intacto seria expor-se demais. Como cavador de buracos relativamente rasos o índios não tem rival, mas não tem a necessária coragem para cavar poços profundos, tão grande é o mêdo de cair no abismo que a tradição lhe inculcou na mente.

Conta outra lenda que uma índia, que não era boa mãe para seus muitos filhos, pois gostava de negar-lhes a comida que pediam, foi queimada por um certo pajé e transformada em porco, tanto ela como os filhos. Até então, só havia no mundo o porco caititu. Quando, de manhã, os índios viram a nova espécie e ouviram do oaiangá responsável o que tinha acontecido, decidiram, em concílio, que os novos porcos não podiam ficar na aldeia ou na mata, para evitar que alguém matasse e comesse carne de origem humana. Foram êles levados para uma caverna ao pé da serra e a entrada foi fechada com um monte de pedras. 
Dias depois, o oaiangá abriu a cova e matou dois porcos, que assou. $\mathrm{Na}$ aldeia, os índios ficaram desconfiados ao ver a carne moqueada, porém tiveram receio de falar diretamente com o temido pajé. No dia seguinte, na ausência dêle, perguntaram ao filho onde o pai tinha achado os porcos. O menino respondeu que não podia mostrar o lugar por estar com o pé doente, mas foi carregado nas costas de um e obrigado a guiá-los até a caverna. Quando tiraram as pedras para conferir o número de porcos, havia muitos, pois êles já tinham se multiplicado. Enraivecidos e hostis, por estarem presos, lançaram-se sôbre os índios, que foram obrigados a voltar para cima. E o menino, que não pôde fugir como os outros por causa do pé, foi pisado pelos porcos e depois de morto, devorado por êles, restando apenas a ferida.

Quando o pajé soube da morte do filho, juntou a ossada, com a ferida do pé, e, abanando e soprando, o fêz reviver. Na sua raiva, fêz o primeiro terremoto, gerando as montanhas, os rios e os vales. Abriu-se um caminho, da caverna para o subterrâneo, por onde os porcos que ficaram presos desceram e lá estão até hoje, fazendo de vez em quando a terra tremer.

\section{O Pai dos Pássaros}

"No dia 26 de novembro de 1954, um avião Lodestar, sob o comando do Major Leal Neto, depois de abastecido em Conceição do Araguaia, rumava para o "Pôsto Indígena Capitão Vasconcelos", no rio Kuluene. Após uma hora de vôo, o pilôto localizou uma aldeia de índios desconhecidos. Ao passar por cima da aldeia, numa altura de 300 metros, foram recebidos por uma saraivada de flechas que chegaram até meiaaltura, deixando ileso o aparelho. Supunham que fôssem os famosos Suyás, índios do grupo jê, que, após um contacto mantido em $1884 \mathrm{com}$ von den Steinen, nunca mais aceitaram aproximação com os civilizados". (O Cruzeiro, 16 de abril de 1955).

Por que querer flechar um avião? Anos antes os Xavánte não fizeram a mesma coisa? A atitude foi devida à ordem de algum cacique intratável ou representou um gesto espontâneo da parte dos índios?

E' possível que o mito de Ok-tí, o Pai dos Pássaros, conhecido por tôdas as tribos jê, explique a atitude hostil com que receberam o primeiro avião.

Conta o mito que uma índia foi ao campo apanhar tucum, levando consigo dois sobrinhos pequenos que brincavam no capim enquanto ela enchia o cêsto de frutos. De repente, houve um ruído como se fôsse uma ventania, e os meninos viram descer dos ares um monstro, de asas abertas, que se arremessou sôbre a mulher e levantou vôo com ela nas garras. Aterrorizados, os meninos acertaram com dificuldade o caminho da aldeia, onde contaram a 1... ória. 
Naquele tempo, os índios eram mansos e sem armas, e não tinham defesa contra os ataques de Ok-tí, o monstro dos ares. O pai dos meninos nunca se esqueceu da irmã desaparecida e queria que os filhos, uma vez crescidos, vingassem sua morte.

Notando um dia que os objetos, quando submersos, parecem assumir tamanho maior, o índio teve a idéia de criar seus filhos debaixo da água. Da casca do jatobá, inteiriça, confeccionou um compartimento que comportasse seus filhos. Embarcando-os com quantidades de beijus de mandioca, e tendo lacrado com resina as costuras da casca, lançou-a, qual submarino, na profundeza das águas. De tempos em tempos tirava-a por meio de um cipé grosso e notava, satisfeito, que os meninos iam crescendo. Depois de feito novo abastecimento, repunha o submarino no leito do rio.

Assim foi que, mais tarde, apareceram entre o povo dois jovens bonitos, mais altos e fortes do que todos os outros. Corriam mais do que as emas. Matavam antas e carregavam-nas inteiras para a maloca, dizendo às mulheres que tratassem dos "ratinhos" que haviam matado. Também fizeram uma casa grande, onde fabricaram armas de madeira, tais como cacetes, lanças e espadas, ensinando a seus patrícios, até aí tão mansos, a manejá-las. Apenas não inventaram o arco e a flecha, cujo segrêdo ainda estava com a onça pintada.

Durante todo êste tempo, o monstro Ok-tí nunca deixou de perseguir os índios e os dois heróis resolveram procurá-lo e matá-lo. Localizaram o seu ninho na copa de uma árvore enorme, a cujo pé havia montes de restos humanos, como ossadas e cabelos, colares e madrepérola e tipóias de fibras.

Os dois armaram, então, uma forte tocaia, camuflada de ramos e fôlhas, de onde tocaram uma buzina para chamar a atenção da ave. Quando esta desceu para investigar, deixaram de buzinar. Não descobrindo nada, Ok-tí subiu mistificado ao seu ninho. Quando, logo ao chegar, ouviu novamente o som dâs buzinas, Ok-tí, irritado, fêz uma segunda descida, ainda sem nada descobrir. E assim por diante, subindo e descendo, cada vez mais vexado e enraivecido, até que cansou. Era o momento que os dois heróis aguardavam e, de cacête na mão, entraram em luta corporal com o monstro, exterminando-o.

Vitoriosos, os índios todos se reuniram para a festa e depenaram Ok-tí para poder devorá-lo como vingança das muitas vítimas. Mas os dois heróis ainda não haviam completado a façanha. Começaram a soprar as penas da ave e logo estas viraram pássaros, variáveis em tamanho e côr conforme a pena que se originaram. Da penugem surgiu o beija-flor.

Assim foi, afirmam os índios, que o mundo se povoou de aves. As$\operatorname{sim}$ foi que aprenderam os princípios da valentia. Assim foi que surgiu 
o costume, até hoje observado, de se construir, no meio de cada aldeiamento, uma casa grande, onde os homens fazem suas armas de pau. E, como durante o combate com Ok-tí, os heróis ficaram com vestígios de penugens nos cabelos, o índio de hoje não se considera completamente enfeitado se não tiver nos cabelos, fixadas com resina de almêcega, semelhantes lembranças de seus ilustres antepassados.

E' muito provável que os índios Suyá tivessem identificado o avião do Major Leal Neto com o Ok-tí das suas tradições e que, por isso, o tivessem recebido com uma saraivada de flechas.

\section{Os antropófagos e o chôro}

Quando, no inverno de 1954, um avião do C.A.N. pousou no campo do pôsto indígena Nilo Peçanha, trazia como passageiro um índio que tinha saído do meio do seu povo havia muitos anos. Ao avistar e reconhecê-lo, uma índia começou a chorar em voz alta, soltando verdadeiros gritos de emoção e, ao mesmo tempo, ferindo a própria cabeça com repetidos golpes de facão, a ponto de o sangue se misturar às lágrimas.

O comandante do avião, embora bastante familiarizado com costumes indígenas, ficou mudo e imóvel perante o estranho espetáculo, pois não parecia haver motivo para aquêle paroxismo assombroso.

A índia, porém, correspondia apenas a um padrão tradicional de sua tribo. Segundo o mito que segue, o costume começou com a morte de Nhetí, o Antropófago.

Diz-se que nos tempos remotos os índios eram todos mansos. Os homens não usavam arco e flechas; não raspavam as cabeças, nem pintavam os corpos, pois não eram guerreiros. As mulheres, por sua vez, eram menos espirituosas do que hoje e, quando choravam, derramavam as lágrimas sem grande pranto, soluçando em voz baixinha, como hoje, dizem elas, choram as mulheres civilizadas.

Os índios de então, devido a sua mansidão, viviam perseguidos por inimigos, os quais nem todos eram do gênero humano. Havia, por exemplo, uma ave monstruosa chamada Ok-tí, que se alimentava dos índios indefesos que encontrava, e cujos ossos e enfeites juncavam o chão em baixo do ninho. (Conta-se também o mito de Olk-tí, o Pai dos Pássaros).

Os índios também sofriam freqüentes incursões dos "Kuben-Kókre", uma raça de antropófagos. (Kuben é "gente"; kókre ou ka-ókre é imitação, que não é verdadeiro, etc.).

Uma vez, os índios procuraram vingar-se. Verificaram que a aldeia dos Kuben-Kókre ficava acima de um penhasco vertical, tão liso que ninguém podia subir, e tão extenso que atravessava a floresta tôda, não permitindo rodeio para se fazer ataque por detrás. Mas, graças a um cipó grosso, que pendia pelo penhasco, de alto a baixo, foi escalado o obstáculo, assaltando-se a aldeia do inimigo. Os índios, porém, eram dema- 
siado mansos para vencer e o assalto fracassou. Escapou apenas um velho, sendo os outros expedicionários devorados pelos Kuben-Kókre. Pior foi ainda quando apareceu, na própria aldeia, um gigante de nome Nhetí, que matava crianças comendo-as à vista das mães, que nada podiam fazer senão chorar em voz baixinha.

Afinal, apareceram dois heróis que haviam de livrar o povo dos seus opressores, e de substituir a mansidão pela virtude até então desconhecida, a valentia.

Conseguiram matar Ok-tí, que é outra história, e, tendo salpicado o cabelo com a penugem da ave morta, prepararam-se para dar combate a Nhetí, o Antropófago.

No meio dos preparativos, o monstro matou e devorou um sobrinho dos heróis! A mágua foi tão grande que êstes, julgando indigno e insuficiente o chôro comum, inventaram o pranto alto e penetrante, com bramidos de dor e aflição. Depois', os dois passaram carvão pelos olhos, para amedrontar o giganite, a quem conseguiram matar.

Os dois heróis figuram nas tradições de tôdas as tribos Jê. Seus nomes variam de maloca em maloca, assim como os pormenores de suas numerosas proezas. São reconhecidos como os patriarcas da nação e os fundadores de tôda a organização social da atualidade.

Como até hoje os guerreiros salpicam o cabelo com a penugem de aves, e passam carvão ao redor dos olhos quando querem fazer medo, assim também usam as mais violentas expressões de luto, julgando estas condignas com o regime da valeritia há tantos séculos estabelecido pelos dois heróis.

Explicada, assim, a origem do chôro presenciado no Pôsto Nilo $\mathrm{Pe}$ çanha, só resta justificar a sua ocorrência numa ocasião que era de grande alegria e não tristeza. Não tinha voltado o filho pródigo da terra longínqua dos civilizados?

Ha três razões para o pranto dos índios que recebem os seus parentes depois de longa ausencia. Primeiro, para indicar a grande falta sentida nêsse período. Em segundo lugar, em memória dos membros da família falecidos durante a separação. Em terceiro, em comiseração pelo que agora voltou, mas que longe dos seus queridos deve ter sofrido muito.

\section{Contos da cozinha}

Os índios jê não fazem cerâmica. Não fabricam nem usam panelas e potes. Onde a civilização não penetrou, não dispõem de outros recipientes para ferver água senão a casca de jaboti ou a casca do côco. Mas não sentem falta de outras vasilhas, uma vez que só bebem água, e não gostam dos mingaus, tão apreciados pelos Tupí.

Tudo quanto que se cozinha é assado no $k i$, espécie de fogão quase exclusivo das tribos do grupo jê. Consiste em uma quantidade de pedras quebradas, do tamanho de um côco, que as índias amontoam numa 
fogueira de lenha. Queimada a lenha, deitam a comida sôbre pedras quentes, colocando por cima outra camada de pedras, para que tudo fique assado por igual. Para conservar o calor durante o processo, cobrem tudo com um fôrro de fôlhas de bananeira, rematado com uma camada de terra, que dá ao ki o aspecto de uma sepultura aberta.

Devido à longa prática, as índias calculam com perfeição o tempo necessário para assar as diversas comidas, seja jabuti, anta, peixe, batata ou beiju de mandioca.

As índias trabalham em grupos, sendo o ki propriedade comum. Em tempo bom, fazem o ki ao ar livre, mas em tempo chuvoso abrigamno. E aí está a origem da "casa" do índio jê. Chama-se ki-kré. (Kré em jê é equivalente a kwára em tupí. Kikré significa, pois, "abrigo para o fogão").

Quanto à origem dêste sistema de preparar os alimentos, conta-se que um dos ancestrais da tribo (um dos dois heróis do mito "Pai dos Pássaros") mandou preparar um beiju de mandioca, e, tomando-o nos braços, mandou que ao redor de si fizessem uma fogueira. Antes que ateassem o fogo, o índio transformou-se em pedra. O calor era tanto, que as mulheres tiveram mêdo, e para que a pedra não se partisse, jogaram água sôbre ela. Mas o beiju já estava assado e o homem vinha retomando a forma natural.

Antes de entrar na fogueira, o índio tinha a pele branca como todos naquêle tempo, mas saiu um tanto queimado e de côr vermelha. O mesmo mito explica a origem das pedras fragmentadas do $\mathrm{ki}$ atual.

Outra história é a de um índio que se zangou com o fogo porque um sobrinho havia se queimado casualmente. Mandou preparar o $k i$. "Onde está a carne para assar?" perguntou a mulher. "Isso é comigo" respondeu o homem. E depois de bem aquecidas as pedras, deitou-se sôbre elas, ficando bem assado. Feito isto, levantou-se e caminhou ruino ao rio, onde desapareceu.

'Tempos depois, voltou completamente restaurado. Quando perguntaram de onde vinha, o índio respondeu que tinha passado o tempo todo com os peixes do rio e, como prova da veracidade do que dizia, mostrou, em seus longos cabelos, os peixinhos que neles se haviam agasalhado.

Os peixes com que vivera eram as mulheres que outrora haviam abandonado a forma humana. Durante o tempo em que esteve em sua companhia, o índio aprendeu várias canções que se perpetuaram no repertório indígena.

\section{A doscoberta do milho}

Uma índia, ao banhar-se com seu netinho, sentiu alguma coisa tocar-lhe o ombro. Olhou e viu um ratinho. Deu-lhe um tapinha de leve, fazendo-o cair na água, mas o rato voltou ao mesmo lugar. Depois de várias investidas, sempre sem resultado, o rato falou com voz humana: 
"Vovó, não me desprezes que eu te mostrarei uma grande novidade". E a seguir lhe deu um grão de milho que naquêle tempo era desconhecido. Até então os índios comiam orelha-de-pau (Urupê) e farelo de árvores em decomposição.

Quando viu que a mulher gostou da nova comida, o ratinho ofereceu-se para mostrar-1he, na floresta vizinha, o lugar onde o tinha achado. Encontraram o chão salpicado de grãos amarelos e vermelhos e a índia ficou admirada de que pudesse haver ali tanta abundância, sem que alguém jamais a tivesse descoberto. Não havia indicíos de onde as sementes tinham vindo: nem fôlhas, nem espigas, nem mesmo sabugos. Parecia que os grãos tinham caido do Céu.

$\mathrm{Na}$ aldeia, os homens mais velhos examinaram as amostras que a mulher levara, dando-lhe o nome de "semente de capim" e as índias passaram a ir colhêr o milho.

Um dia, alguém observou que os grãos provinham de uma árvore enorme, em cujos ramos, que cobriam o local todo, grupos de araras e macacos comiam, debulhando as espigas e fazendo o milho cair na terra. Os índios, em concílio, resolveram derrubar a árvore.

O tronco era de uma grossura tal, que um dia de trabalho não foi suficiente para concluir a tarefa, apesar dos muitos machados que se empregavam ${ }^{1}$.

Quando, na manhã seguinte, voltaram à obra, viram que o corte do dia anterior estava fechado por completo, porque a árvore era encantada. Isto se repetiu muitas vêzes até que os índios resolveram reunir tôdas as suas fôrças numa tentativa final: todos trabalhariam sem parar, a fim de terminar a derrubada antes do pôr do sol.

Alguém se lembrou de um machado que ficara em casa e enviaram dois meninos para buscá-lo a tôda a pressa. Mas êstes encontraram uma mucura numa fôlha de marajá (tipo encontrado sòmente nos campos e não na mata) e se demoraram para matá-la e comê-la. Quando terminaram, sentiram-se de tal maneira envelhecidos, que o machado se tornou um verdadeiro fardo e foi com a maior dificuldade que, decrépitos e esgotados, conseguiram arrastar-se até a árvore que estava sendo posta abaixo.

Quando viram que a árvore estava dominada, os índios fizeram uma grande festa, dançando e cantando ao seu redor até o momento em que a mesma estalou e caiu. Desde então, os indígenas nunca perderam a semente do milho milagroso. Não admitem que o milho amarelo dos civilizados seja da mesma origem, sendo êste, na opinião dos índios, embora mais novo, mais duro e inferior.

$\mathrm{E}$ até hoje, todos os anos os índios celebram a "Festa do Milho", executando as mesmas danças e canções que seus antepassados inventaram no dia da vitória sôbre o pé original. Mas não se chama mais "se- 
mente de capim". O nome usado hoje é "semente da floresta". Qual o motivo? Eles próprios o desconhecem.

Quanto aos meninos que envelheceram, foram debalde todos os esforços dos pajés para rejuvenecê-los, e, até hoje, ninguém se atreve a comer mucura ou gambá.

Os índios afirmam que até a descoberta do milho êles eram relativamente poucos. Falavam uma só língua e andavam como um só rebanho. Mas, de posse do cereal destinado a ser o futuro alimento principal, dividiram-se em tribos e cobriram tôda a face da terra. Como o mitho não tem rival entre os cereais pela sua fecundidade, os índios entraram numa fase de grande multiplicação. Foi também nessa ocasião que apareceu a variedade de línguas e costumes entre os diversos povos. Atribuem a tôdas as tribos uma origem comum e o mito do pé de Milho ocupa, em suas tradições, um lugar comparável à Tôrre de Babél na História Sagrada.

\section{A Mãe das Cobras}

Certo casal, por um motivo qualquer, saiu da maloca e fêz roça em terra distante, resolvido a morar ali.

Uma tarde, quando o homem foi banhar-se, transformou-se em cobra, pois as águas do igarapé eram encantadas sem que êle o soubesse.

Arrastou-se para casa, onde a mulher, ao avistar o monstro, levou um grande susto, pois até aquêle tempo não havia cobra no mundo. Começou a gritar para que o marido viesse matar o bicho estranho, porém calou-se quando, da bôca da cobra, ouviu a voz familiar do seu companheiro: "Sou eu".

O homem-cobra não se importava mais com sua lavoura, mas caçava todos os dias, com ótimos resultados, pois os animais não sabiam defender-se dêle. Crescia com uma rapidez extraordinária. Tão grande era o seu apetite, que um fogo só se tornou insuficiente para prepararthe a comida. A mulher cercou a casa de fogos. Enquanto ela preparava as refeições, êle esperava impaciente e intolerante. A mulher despejava-lhe a comida pela bôca a dentro e, com o estômago cheio, o monstro se acalmava e ia dormir.

Por êsse tempo, o povo da maloca enviou um mensageiro para ter notícias do casal desaparecido. Como êle não soubesse para onde se dirigir, subia, de vez em quando, em qualquer árvore alta, na esperança de ouvir algum sinal de vida humana. Um dia ouviu, à distância, o som de quem pilava milho ou mandioca e, orientando-se por êle, descobriu a morada do casal.

O homem-cobra não estava em casa, mas a mulher contou a história do seu encantamento, em que o índio não quis acreditar. "Passa a noite aqui e verás", disse ela. 
O mensageiro escondeu-se debaixo de uma esteira que cobria um monte de milho sêco num girau. De madrugada, tendo êle se certificado de tudo, partiu para aldeia com a história.

Curioso, outro índio empreendeu a viagem também e se escondeu no mesmo lugar. Mas quando, depois de ter ceado, o monstro começou a cantar, o outro não pôde se conter e começou a cantar também. Houve uma pausa.

"O que é aquilo?" perguntou o monstro.

"Nada, apenas o eco da tua própria voz", replicou a mulher. O homem-cobra tornou a cantar, mas, com uma segunda interrupção, resolveu investigar o que se passava. Descobrindo o intruso, matou-o e comeu-o.

Quando, mais tarde, veio um terceiro índio e soube da triste sorte de seu companherio, partiu sem demora para a aldeia, onde reuniu todos os guerreiros em expedição punitiva. Cercaram a casa e ficaram escondidos até que, depois da ceia, o monstro dormiu. Então o liquidaram com os tacapes.

A mulher, que não tinha consentido na morte do marido, foi levada para a aldeia onde, mais tarde, deu à luz uma ninhada de cobrinhas de tôda espécie. Os meninos da maloca, armados de cacetes, esperavam o momento do parto para matar-lhe a prole; porém, a mulher defendeu-a e ajudou os filhotes a colhêr o milho sêco na roça ao redor.

"Ide embora, meus filhos!" disse ela. "São êles, os filhos dos malvados que mataram o vosso pai. Ide embora e vingai-vos quando puderdes".

E' êsse o motivo, dizem os índios, da inimizade que até hoje existe entre os filhos da cobra e os dos homens.

\section{O primeiro cantor}

Contam os índios que o primeiro cantor foi a anta, embora hoje só the reste a faculdade de sibilar.

Perdido na mata e sem saber onde passar a noite, pois o sol já havia declinado, um índio viu ao longe um fogo. O fogo era do inambu azulão, ave que faz ninho no chão. O índio pediu um lugar à beira-fogo, o que the foi concedido sob a condição de êle não soprar o lume. Tudo foi bem até a madrugada, quando, sentindo o frio e esquecendo-se do aviso, o índio soprou o fogo. O sôpro arrepiou as penas do hospedeiro que, contrariado, levantou vôo, carregando seu fogo e deixando o índio com frio e desconsolado. Mas êste recobrou o ânimo ao ouvir alguém cantar. Levantou-se e se encaminhou na direção da voz. Porém, sem luz, era difícil acertar com o local. Nada enxergando, procurou às apalpadelas a cabeça do cantor. E qual não foi o seu susto ao descobrir que a voz provinha da caveira da anta! 
Em outra ocasião, um índio queimou-se quando ajudava a assar uma anta. Louco de dor, começou a correr em círculo, até que, finalmente, se transformou em anta e desapareceu. Seu irmão procurou-lhe o rastro por muitos dias até que chegou ao Lago das Antas, a matriz de onde as antas saíam pelo mundo todo. As antas estavam em festa, fazendo uma grande roda ao redor de um casal. O índio, que espreitava, viu que o macho do casal era o irmão desaparecido, que conservava a cabeça humana num corpo de anta. Conseguiu afastá-lo da companheira e, por meio de encantamentos, restaurá-lo à forma humana. Voltando à aldeia, o índio ensinou aos companheiros tôdas as canções que aprendera enquanto anta. E até hoje, a companheira abandonada pode ser vista a vagar, ouvidos atentos, focinho erguido no ar, sibilando... sibilando... em busca do parceiro perdido.

\section{Um mito do bacurau}

O bacurau é ave noturna, de côr escura e sem brilho, que se encontra nos descampados, nos terreiros de casas do interior e nas estradas. E ave de asas grandes, mas de vôo baixo e agitado, esvoaçando de bôca aberta, a caçar os insetos que de noite infestam os ares. Na Europa é conhecido como caprimulgo ("goat-sucker" em inglês), pois, volteando pelos úberes dos animais, dá a impressão errônea de estar à procura de leite.

O bacurau não faz ninho. A fêmea deita os ovos, que são geralmente dois, na poeira do chão, onde o pêso do corpo faz uma ligeira depressão. Aos que se aproximam dos filhotes a mãe procura distrair por vôos oblíquos, como de asa quebrada, assim chamando sôbre si a atenção dos intrusos, a que consegue levar cada vez mais longe da prole.

O bacurau sabe bater as asas uma contra a outra e, com o bico fechado, sussurra como um motorzinho, clamando "ba...curau!" Sobe da poeira em vôo vertical, por uns momentos paira como helicóptero a dois ou três metros de altura, e desce novamente, devagar, silencicsa e alerta.

Do bacurau, cujos hábitos os indígenas tão bem conhecem, contase nas malocas Kayapó o seguinte mito:

Certo índio não era bom marido, pois maltratava a mulher e fazia-a de escrava. Uma vez, sairam os dois para uma caçada. Como de costume, - homem dava à mulher bem pouca carne, e de água, que era escassa na região, nem uma gôta. Uma tarde, a sêde era imensa, porém o marido não permitiu que a mulher fôsse com êlle quando saiu do rancho à procura de água. Voltou dizendo que nada tinha encontrado, mas a mulher não lhe acreditou, pois os sapos, cuja voz é indício infalível da presença de água, ccaxavam fortemente a uma distância não muito grande.

Depois de o marido adormecer, a mulher queria ir em busca de água para matar a terrível sêde, porém receava a altitude do maridc, se êste, acordando, desse pela ausência da companheira. Teve ela então a 
idéia de dividir-se, por meio de mágica, deixando o corpo ficar na cama, enquanto a cabeça, cujos cabelos serviriam de asas, voasse aonde estavam os sapos, à beira do poço. Mesmo assim, o marido descobriu a falta da consorte, e, enraivecido, espalhou as brasas do fogo, jogando-as em tôdas as direções, de maneira que a cama ficou numa escuridão total.

A pobre mulher, isto é, a cabeça, voava aqui e acolá pela noite tôda, sem acertar o lugar onde jazia o resto do corpo. De manhã cêdo, o malévolo marido secou o cadáver em cima do moquém, e levou-o para a aldeia, onde o entregou aos pais.

Afinal, desconsolada, a cabeça-sem-corpo virou bacurau. Como tal ainda anda no luar, de vôos baixos e agitados, os cabelos longos da primeira encarnação transformados em asas que flutuam e esvoaçam à procura do lugar em que, há tantos anos, ficou privada da sua forma humana.

\section{A primeira risada}

De onde vem o riso? Quem foi que deu a primeira risada? Como? Quando? Por quê?

No mito que se segue, os Kayapó oferecem a explicação.

Certo índio deixou de acompanhar os outros à caça e foi trabalhar na roça. Tendo sêde, foi à procura de água num poço que conhecia na mata vizinha. Ao abaixar-se para beber, ouviu um ruído estranho, um mumúrrio que vinha de cima. Olhou e viu uma criatura desconhecida que, de cabeça para baixo, o espreitava de um galho pendente. Era um "Kuben-niêpre", com corpo de homem e asas e pés de morcêgo.

Mostrando-se amigo, Kuben-niêpre desceu e, visto não saber falar em língua humana, começou a acariciar o índio, que não gostou do gesto. As mãos frias, de unhas compridas, esfregavam-lhe a pele com tanto entusiasmo que provocaram cócegas, fazendo com que êle risse. Foi a primeira risada ouvida no mundo.

Depois, Kuben-niêpre tomou o índio pelo braço e levantou vôo rumo a uma caverna, onde morava o resto do gênero homem-morcego. Tratava-se de uma casa alta de pedra, em cujo chão não havia nenhum objeto e que era coberto apenas com as fezes das hordas que viviam suspensas na abóbada. As paredes estavam adornadas com desenhos e figurinhas, de alto a baixo.

O visitante foi bem recebido, e as carícias que tinha recebido à beira do poço se multiplicaram. As cócegas e gargalhadas, porém, acabaram por esgotá-1o e êle caiu prostra do no chão, sem sentidos. Durante muito tempo, não teve fôrça suficiente para escapar e ganhar a maloca.

Os índios se indignaram ao ouvirem falar do tratamento dispensado ao companheiro e organizaram uma expedição punitiva. Chegaram de dia à casa de pedra, hora em que os ocupantes estavam dormindo. Amon- 
toaram muitas fôlhas sêcas e, depois de fechar com pedras a abertura, atearam fogo. Não foi possível, porém, asfixiar os Kuben-niêpre, pois havia uma saída por cima e todos escaparam, com exceção de um filhotinho que foi apanhado vivo.

O cativozinho deu-se mal na aldeia, até que alguém teve a idéia de fazer-lhe um poleiro onde pudesse dormir de cabeça para baixo. $\mathrm{O}$ menino-morcego chegou a aprender a andar e a passar o dia no chão, mas nunca dormiu senão no alto. Infelizmente, não teve vida longa.

Até hoje o índio de tipo guerreiro pouco aprecia a risada, considerando-a indigna de sua posição e própria, apenas, como as cócegas, às mulheres e crianças.

\section{A origem da doença}

Bem recordo a minha admiração quando os índios me deram a palavra kapremp para duas coisas absolutamente diferentes, e, em meu parecer, sem relação nenhuma. Que há de comum entre um acesso de impaludismo e um despenhadeiro ao lado da serra?

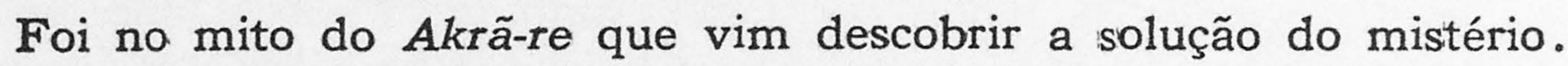

Antigamente, dizem os índios, não havia no mundo qualquer doença. Se alguém morria, era ou em combate, ou de velhice.

Um dia, descobriram um ninho de garça, e, dentro, um filhote que se parecia com garça, mas era um tanto diferente. Levaram a ave para a aldeia, onde the deram o nome de Akrã-re. Ficou mansa e amiga de todos. Gostava muito de um pilão grande que, cheio de água, substituía o lago que as garças tanto apreciam.

Passou muito tempo, e quando Akrã-re cresceu, houve na aldeia um grande estrondo, como trovão, porém no meio das casas. O pilão ficou envolto em fumaça. A água ferveu, e no meio de tudo, eis Akrã-re, indiferente ao calor, limpando as plumas. Daí a pouco, levantou vôo e desapareceu.

Certo tempo depois, os índios foram "tinguijar" o lago. Enquanto esperavam os peixes boiarem, as mulheres sentaram-se numa praia e viram que Akrã-re estava olhando, de uma árvore vizinha. De repente, a ave desceu, com outro estrondo. Não tocou em ninguém, porém todos caíram, muitos morrendo com os peixes que haviam envenenado.

Foi assim, dizem os índios, que a doença entrou no mundo. Até hoje não gostam de ver qualquer ave grande que voe rumo à maloca. Atiram, gritam, procuram todos os meios de desviá-la das casas. Lembramse de $A k r a \tilde{-}-\mathrm{re}$ e receiam nova visita.

Quanto ao despenhadeiro, que também é conhecido por kapremp, a explicação é fácil.

Onde há serras enflorestadas, são comuns os desabamentos de terra. Quando as árvores crescem em encosta íngreme, a terra não suporta o 
pêso e as quedas resultantes deixam um precipício despido de vegetação.

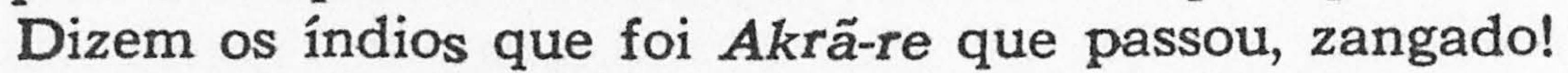

Kapremp, então, não é nem acesso de febre, nem despenhadeiro; é - "feitiço" de Akrã-re, a ave malévola, que se manifesta em convulsões e fenômenos semelhantes, quer no gênero humano, quer no reino vegetal.

\section{Perna-ponteaguda}

Um índio, ferrador de arraia, viu seu pé apodrecer e cair. $\mathrm{Na}$ extremidade da tíbia, que ficou exposta, fêz-se uma ponta, e êle recebeu o apelido de Te-djuáre, Perna-ponteaguda.

Quando o povo abandonou o acampamento e foi para outro lugar, Tedjuáre se sentiu triste e humilhado pela necessidade de ser carregado pela mulher. Mandando a mulher abaixar-se, em lugar de montarthe nas costas, Tedjuáre transpassou-lhe a nuca com a ponta do osso.

Daquele momento em diante, tornou-se perseguidor dos indios: voava pelos ares, matando um e outro, sempre furando as vítimas na nuca.

Em represália, os índios resolveram matá-lo. Fizeram uma imagem de guerreiro em madeira mole, completaram-na com adornos de penas e armas, e pintaram-lhe o rosto de prêto como para brigar. Um portavoz, escondido atrás da imagem, desafiou Tedjuáre a que aparecesse a dar combate. A emboscada teve o êxito desejado: Tedjuáre lançou contra o "inimigo" com tanto ímpeto que a perna ficou espetada e êle não a pôde retirar. Foi, assim, prêso e morto a cacetadas.

Tempos depois, as mulheres foram apanhar bacaba. Uma já estava trepada na bacabeira quando se ouviu um grito: "Lá vai Tedjuáre!" Êle não possuía mais corpo. Apenas a cabeça e os ombros iam subindo pela bacabeira. A mulher defendeu-se furando-lhe o pescoço com a casca do cacho de bacaba que tinha na mão e fazendo-o cair por terra, onde os índios acabaram de matá-lo.

Os índios não temem mais a perna-ponteaguda de Tedjuáre, de quem aprendarem o valor do osso em ponta. Uma das armas prediletas dos Kayapó é o rop-í, a lança feita com ponta de tíbia de onça.

\section{O mito do castanheiro}

Contam os índios que a castanheira do Pará (Bertholletia excelsa), atualmente a rainha das selvas por ser a árvore mais alta, ocupa hoje o lugar que outrora pertenceu à bacabeira. Antes de chegarem às matas setentrionais, não conheciam outra castanha além da sapucaia.

Dizem que foi grande a admiração quando certo caçador chegou na aldeia com o primeiro ouriço de castanha do Pará. No dia seguinte, o descobridor levou um cunhado para ver a estranha árvore e, para melhor examinarem o fruto e a fôlha, subiram ambos por ela acima. Naquêle tempo, a castanheira era pequena, mas tinha as fôlhas tão grandes 
como hoje. Elas caiam ao chão lenta e demoradamente. Sem que o companheiro reparasse, o descobridor, que era feiticeiro (ôaiangá), colocou uma fôlha entre os dedos do pé, à guisa de paraquedas, e saltou.

Quando o índio sentiu a falta do outro na árvore, ficou espantado, principalmente quando o viu já em baixo. Perguntou como tinha descido. Mentindo, o pajé afirmou ter descido pelo tronco, no que o companheiro não quis acreditar. Afinal, o feiticeiro revelou o segrêdo da fôlha-paraqueda, mandando que o outro descesse da mesma maneira. Êlefêz a tentativa, mas a fôlha não suportou seu pêso, e êle caiu e morreu.

Dias depois, quando os urubus acabaram de devorar o cadáver, o ôaiangá veio e, soprando sôbre os ossos, fêz com que se unissem e revivessem. Levantando-se, o ressuscitado perguntou o que the tinha acontecido e, quando soube, ficou com muita raiva. Apanhou uma palma de bacabeira e com ela surrou o tronco da castanheira. Esta, emitindo uma zoada como de cachoeira, começou a crescer, à vista de ambos, esticaindo-se palmo a palmo à medida que recebia as pancadas.

O homem só deixou de surrár quando não aguentava mais de cansaço. Mas então a copa da castanheira já tinha sobrepujado as demais. árvores da floresta, transformando-se, assim, na rainha das selvas que até hoje é.

\section{O primeiro machado de ferro}

O machado original dos Kayapó é o "ukát", feito de pedra. Naquele tempo era dificílimo a extração de mel de abelha e palmito. Um índio, andando perdido pela mata, viu um homem-macaco (Kubẽ-kukoi-tá) espreitando-o de uma árvore. Andava êste com um machado de ferro no ombro, amarrado com embira.

"Dá-me o machado para eu também poder comer palmito e mel", gritou o Kayapó.

"E' só êste que tenho!", respondeu o homem-macaco.

A conversa tornou-se hostil e quando o Kayapó lhe atirou uma flecha, o homem-macaco arremessou-lhe o machado.

Na aldeia, o machado de ferro despertou grande interêsse e muitos. índios viajaram até as terras dos homens-macacos na esperança de adquirir outros.

Mas hoje é mais fácil roubar os machados dos Kubẽ-krút (os Homens de Metal, os brancos) do que de Kubé-kukoi-tí.

\section{O Lago dos Cães}

E' difícil encontrar índios, por mais isolados ou intratáveis que sejam, que não possuam cachorros domesticados.

Que o cão não é indígena é indicado pelo vocabulário das várias tribos que não fazem distinção entre caninos e felinos e empregam o diminutivo de onça (iauára em tupi, e rop em jê) para descrevê-lo. 
De onde vem? A resposta mais razoável é que foi adquirido dos civilizados ocupantes da mesma terra, em contactos pacíficos ou belicosos. E, no caso, o cão tem andado muito na frente de seu dono e domesticador, penetrando a "cortina verde" das malocas e precedendo o homem civilizado de dezenas de anos.

Mas, para o índio, o cão teve princípio mais digno, origem mais nobre do que o quintal do branco. Vem, como a onça, do Lago dos Cães, que a tradição localiza na vastidão de Mato Grosso.

$\mathrm{E}$ contam os índios:

Por ocasião de certa festa, as 'mulheres jovens estavam se pintando para dançar. Entre elas, apenas uma se mostrava triste e indiferente aos preparativos. "Agora é a tua vez", disseram as outras. "Por que estás tão triste?" "Acaso é meu marido rapaz novo como os de vocês?", replicou ela.

A queixa da mulher foi ouvida por um sobrinho do velho marido, que foi logo contar-lhe que ela o tinha chamado de velho decrépito perante as outras. O marido sentiu-se humilhado, deixou de comer, abandonou a festa e passou dias inteiros imaginando...

Uma noite, o velho saiu para o meio da praça e cantou uma canção nova que ninguém conhecia. Depois enunciou que se ia embora para nunca mais voltar. Levou consigo a mulher e parentes mais próximos.

Foram para muito longe e tiveram muitas experiências que os índios se perdem em contar. Por exemplo, chegando os viajantes aos confins da Terra Firme, um dêles não viu um pântano à sua frente e se atolou irremediàvelmente. Foi ali que os índios aprenderam a fazer a balsa, pequena plataforma rústica em que transportaram para o outro lado a bagagem que levavam. Até hoje muitas tribos jê, que não fazem canoas, usam as balsas inventadas naquela viagem pioneira.

Além do pântano, encontraram onças numa quantidade inimaginável. Verificaram que elas vinham de um lago que era a matriz de tôdas as espécies, inclusive do cachorro comum.

Quando depararam com um lugar muito escuro, que era a famosa Fonte das Trevas, alguns, medrosos, resolveram voltar à aldeia e o fizeram levando alguns cachorros, que ali se multiplicaram até as proporções atuais. Os outros atravessaram a quase interminável Fonte das Trevas, usando fachos de palha sêca, que prepararam em grande quantidade, juntamente com mantimentos, antes de penetrar na escuridão.

Fizeram uma maloca nova do outro lado daquele lugar de perigos e tomaram o nome de Suyá, nome êsse coníservado até hoje; são, porém, conhecidos na maloca original como "Kruatira" ou Flecha Comprida. 


\section{Relativo aos piolhos}

Quem, dentre os que conhecem a vida de aldeia, não terá ficado admirado ao ver as índias catarem piolhos? $\mathrm{E}$ ainda mais ao notar o prazer com que elas põem fim à existência dos parasitas, triturando-os com os dentes como se dêles se vingassem?

Os piolhos datam do tempo de um velho mau, de nome Krã-kamdjuáre (Dentes na Cabeça). Chamava as cunhãs novas (Me-kureré) para catá-los. Mas, escondidos entre seus longos cabelos, o velho tinha dentes com que mordia os dedos das mulheres. Depois de assim provarlhes o sangue, matava-as, pois era antropófago.

Um dia, o velho chamou uma mulher bonita, que, ao sentir os dentes a mordê-la, gritou "Ai... ai... ai...". Mas quando os parentes perguntaram o que era, ela teve mêdo de contar. Desejava fugir da aldeia. Porém, não sabia como sair sem que o velho o soubesse.

Havia, na casa da mãe da moça, um tatu amigo, que se ofereceu para cavar um túnel, ligando a casa à floresta, para além d circunferência das casas. Foi assim que a mulher escapou pelo túnel, deixando um periquito amigo a cobrir a entrada com as asas.

Mas o velho não demorou a descobrir a fuga da mulher e a segui1a. Desta vez ela achou um amigo na pessoa da Garça (Kubẽ-kamrí), que a engoliu, deixando para fora do bico apenas o fio do colar de madrepérola que ela usava. Tendo passado o perigo, puxou o fio e extraiu a mulher.

Mais tarde, foi o Jacaré (Kubẽ-mi) que se mostrou amigo, atravessando o rio com ela nas costas. Ao chegar à margem de outro rio, com o inimigo sempre a persegui-la, a mulher viu-se só e sem proteção. Casualmente, lançou na água um pedacinho de pau. No mesmo instante, êle foi devorado pelas pirønhas. A mulher jogou outro pedaço, mais grosso, que também caiu nos dentes das piranhas. Foi quando ela teve a idéia de fazer um caminho falso (prù-kaigó), deixando suas pegadas bem visíveis, até a beira da água, para dar a impressão de ter passado a nado. Feito isto, escondeu-se na mata.

Chegou o adversário muito enraivecido e, cheio de pressa, ao ver o rastro da mulher, precipitou-se nas águas, sem notar as piranhas que logo the deram fim à existência.

O velho "Dentes na Cabeça" não existe mais para perseguir as mu1heres. Mas restaram seus piolhos para atormentar os mortais.

\section{A origem dos índios Jurúna}

Havia em certa árvore uma lagarta grande, preta e com a cabeça encarnada. Era encantada (ôaiangá), e à noite, quando os homens da aldeia iam caçar, assumia a forma humana e seduzia as mulheres que ficavam sós. 
Um menino relatou o caso ao pai e êste resolveu passar uma noite acordado para se certificar do fato. Nesta noite, a lagarta não virou homem, mas o índio viu os muitos filhos da lagarta descerem da árvore à procura das mães. Depois de se fartarem, as lagartinhas voltaram à árvore.

Para se vingar, o homem acendeu um fogo embaixo da árvore, fazendo as lagartas pipocar com estalos que pareciam tiros de espingarda.

A lagarta-mestra não morreu com os filhotes. Ganhando o rio, foise embora, erguendo, curvándo e arrastando o corpo por cima da água, à maneira das lagartas quando andam .

Mais tarde, pela mesma água, apareceram os índios Jurúna, que os Gorotíre chamam de "Ngôi-ren" (remadores), pois fazem canoas e gostam muito de viajar por água. E os Jurúna vinham munidos de espingardas, que os Gorotíre não conheciam, acreditando-se que dessem tiros para vingar os estalos causados pelo fogo kayapó ao queimar os corpos dos progenitores da tribo.

\section{A vinda dos brancos}

No tempo em que os índios moravam à beira da Água Grande, um grupo de rapazes deparou com uma grande casa de cupins. Era de barro e o seu tamanho excepcional chamou-1hes a atenção. Atiraram-lhe algumas flechas e depois o furaram com as lanças (rop-i).

Mas os habitantes eram cupins-feiticeiros (ôaiangá), que, na sua raiva, investiram contra os perseguidores, obrigando-os a fugir. Não havia onde se abrigar senão na água. Os índios mergulharam, e os cupins cs seguiram.

Todos os índios desapareceram, com exceção de um, que escapou para contar a história.

Tempos depois os cupins voltaram, porém em forma de homens brancos, em barcos movidos a vela, desenvolvimento das asas de que os cupins são dotados ao sair do chão com as primeiras chuvas. Entre êles havia soldados (Krã-kam-ngoira) e padres (ôaiangára).

A palavra para "soldado" significa "panela na cabeça", referindo-se aos capacetes de metal usados pelos conquistadores. Os índios Urubus e Tembé, que são tupí, usam uma expressão que significa "casca de jabuti", com referência à armadura de aço que lhes defendia o corpo.

Como prova da origem humilde da raça branca, em contraste com a dos Homens do Céu, que são os índios, indicam as casas de barro vermelho, cheias de compartimentos, que os civilizados do interior ainda fazem e que faziam em escala mais reduzida quando viviam na terra como térmitas. NOTA

(1) Os índios afirmam que os machados usados eram de ferro e não de pedra. Vê-se que o milho é muito mais antigo que a lenda, pois foi sòmente com a vinda dos civilizados que o machado de ferro apareceu. 